\title{
RESPONSES OF ABOVE- AND BELOW-GROUND CARBON STOCKS TO ENVIRONMENTAL DRIVERS IN TIBETAN ALPINE GRASSLANDS
}

\author{
Hongsheng LIU, ${ }^{\mathrm{a}, \mathrm{b}}$, Zewei MIAO ${ }^{\mathrm{c}}$ \\ ${ }^{a}$ Institute of Geography Sciences and Natural Resource Research, Chinese Academy of Sciences, \\ 11 A Datun Road, Beijing 100101, China \\ ${ }^{b}$ Department of Biology, University of Texas at Arlington, 701 Nedderman Dr. Arlington, Texas, 76013, USA \\ 'Nicholas School of the Environment, Duke University, 308 Research Drive, Durham, NC 27708, USA
}

Submitted 02 Dec. 2014; accepted 08 Jul. 2015

\begin{abstract}
Paucity in the knowledge of responses of grassland carbon dynamics to environmental variables constrains our ability to predict future ecosystem productivity. The aim of this study was to investigate differential responses of above- and below-ground carbon stocks to environmental drivers in Tibetan alpine Plateau at both regional and local scales. Variance partitioning and non-linear regression between carbon stocks and environmental driving variables suggested that both above- and below-ground carbon stocks showed a significant negative relationship with temperature and a positive relationship with soil moisture. Annual accumulated temperature constrained above-ground carbon at regional scale $\left(r^{2}=0.50, P<0.0001\right)$, while soil moisture controlled below-ground carbon at local scale $\left(r^{2}=\right.$ $0.48, P<0.0001)$. Scale-specific responses of above- and belowground carbon storage to temperature and soil moisture complicated the influences of abiotic environmental variables on ecosystem productivity. Soil carbon had significant unimodal $\left(r^{2}=0.11, P=0.0073\right)$ and linear $\left(r^{2}=0.37, P<0.0001\right)$ relationships with mean annual temperature and soil moisture, respectively. Since the driving factors of aboveground and soil carbon content are specific to spatial scales, the relationships of grassland carbon storage and environmental factors at small scales are not applicable to a large spatial scale.
\end{abstract}

Keywords: biomass, spatial scales, soil moisture, annual precipitation, annual mean temperature, variation partition.

\section{Introduction}

Grasslands play an important role in global terrestrial carbon cycle due to their large area and high carbon density. Grassland stores up to $10 \%$ of terrestrial biomass carbon, $10-30 \%$ of global soil organic carbon, and likely provide an annual sink of $\sim 0.5$ Pg C (Scurlock et al. 2002). Identifying the responses of above-ground and below-ground carbon dynamics to environmental variables is critical to investigate the effect of climate change on grassland ecosystem functions.

The relationship between carbon dynamics, especially belowground carbon and environmental variables, is not certain in Tibetan grassland yet. Majority of previous literature only includes measurements of above-ground carbon or biomass storage (Sala et al. 1988; Swemmer et al. 2007; Yang et al. 2008; Sun et al. 2013). Although belowground carbon has been estimated to account for more than $50 \%$ of the net carbon stocks of grassland ecosystems, fewer studies focused on below-ground carbon in Tibetan plateau (Hendricks et al. 1993; Wu et al. 2011). Relative to the aboveground biomass, determinations of root biomass distribution and belowground processes are much more challenging due to the intensive labour and time consuming. In addition, environmental variables including climate, soil physical, chemical and biological characteristics, and plant properties all affect the distribution of root carbon (Gong et al. 2015; Xu et al. 2015). Therefore, it is important for Tibetan grassland ecosystem management to investigate the effects of environmental factors on belowground carbon distribution in various regions.

The driving mechanism of environmental factors on above-ground carbon and below-ground carbon are different. Above-ground carbon turnover rates increase as moisture availability increases (Chabot, Hicks 1982; Reich et al. 1992; Piao et al. 2006; Bai et al. 2008; Sistla et al. 2013). This has been generalized to roots, and it has been

Corresponding author: Zewei Miao

E-mail: miaozewei@gmail.com 
assumed that root and shoot biomass ratio follow roughly the same extent regardless of environmental conditions (Hendricks et al. 1993; Ostertag 2001; Hui, Jackson 2005). It is specific to environmental conditions for grass to capture nutrients, water, and light, and hence maximize their growth rate and to allocate to carbon among various organs (Chapin et al. 1986; Enquist, Niklas 2002). Thus, environmental drivers and driving mechanism of roots and foliage carbon may be different in allocating carbohydrates between above-ground and below-ground tissues (McConnaughay, Coleman 1999). For example, carbon is primarily allocated to tissues where resources are most limiting (Chapin et al. 1990; Ostertag 2001). Therefore, when environmental variables including moisture are positively related to the above-ground carbon and negatively related to below-ground carbon, the negative influences of environmental variables on soil carbon (SOC) could be offset by high growth rate.

Fewer studies of carbon stocks in Tibetan plateau grasslands have been carried out at a large spatial scale. The influence of environmental factors on plant biomass and soil carbon stock varied greatly from scale to scale. Generally, at a small scale, the above-ground carbon and SOC were controlled by nutrient level and moisture availability, whereas temperature played a much more important role than moisture at a large scale. For example, at local scale, above-ground carbon storage, cycling and their responses to disturbance have been well described by soil properties, soil moisture, grazing (Patton et al. 2007), land use change (Gibbon et al. 2010), nutrient availability (De Deyn et al. 2009), and/or topography (Avohou, Sinsin 2009). At large spatial scales, grass primary productivity had good relationships with regional factors, including annual precipitation (Sala et al. 1988; Bai et al. 2008; Medvigy et al. 2010), variation in annual precipitation (Knapp et al. 2002; Bai et al. 2004), and the interaction of temperature and precipitation (Swemmer et al. 2007). Therefore, environmental drivers of carbon sequestrations and SOC content are sensitive to spatial scales in grassland ecosystems. The cause-effect relationship of ecosystem carbon stock and driving factors discovered at local scales may be invalid at regional and/or global scales. Climatic patterns may be too broad to account for the observed variations in carbon productivity at a small geographic scale. As a result, determining environmental drivers and driving mechanism of carbon stock is of great importance at different scales.

The objectives of this research focus on (a) the driving forces of above-, below-ground, and soil organic carbon content at local and regional scales, (b) partitioning the influences of resources availability on the components of grassland carbon content at local and regional scales, and (c) predicting the influence of climate change on plant and soil carbon content in the Tibetan Plateau. The hypothesis of this research is that the limiting factors of above-, below-ground, and soil organic carbon content are different and scale-dependent. To test the hypothesis, we collected plants and soil samples across the Tibetan Plateau, which is one of the largest alpine grasslands in the world with extending about $2.40 \times 10^{6} \mathrm{~km}^{2}$ in western China. The spatial gradients of temperature and moisture, limited grass species and sparse ecosystem types together with little human disturbance made the Tibetan plateau an ideal study area for investigating response of plant and soil carbon stock to various resources availability.

\section{Methods and materials}

\subsection{Study sites}

Plant and soil samples were collected at 45 sites and 96 quadrates on the Tibetan Plateau grasslands by cutting or grazing during the summer (July to August) of 2010. The climate on the plateau is cold and relatively humid, with mean annual temperature of $1.61^{\circ} \mathrm{C}$ and precipitation of $413.6 \mathrm{~mm}$ (Yang et al. 2008). The altitude of the Plateau ranges from 200 to $8840 \mathrm{~m}$ with mean value of 4000 to $5000 \mathrm{~m}$ above sea level. Information obtained from the vegetation atlas of China with a scale of 1:1000,000 showed that vegetation is mainly dominated by the alpine steppe and meadow, with a total cover of $>60 \%$ area of the plateau (Chinese Academy... 2001). The spatial patterns of alpine grasslands are closely related to the precipitation gradient across the plateau. Alpine steppe occurs in cold and arid regions and consists of xerophytic grasses such as Carex moorcroftii Falc. ex Boott, Stipa purpurea Griseb, and Polygonum viviparum L.. Alpine meadow dominated by Kobresia pygmaea C. B. Clarke is distributed in humid and relatively warm areas. Soil types relate to alpine steppe and meadow are cold calcic and felty soils, respectively, which both have been defined as cambisols in the Food and Agriculture Organization (FAO) soil taxonomy system (Wu et al. 2003).

\subsection{Sampling and measurements}

To achieve systematic sampling, the spatial interval between sampling sites was set at about $100 \mathrm{~km}$. Because of inaccessibility of traffic and limitations of topography, some samplings were conducted along the major roads, while others were more widely spaced and the average distance was $>100 \mathrm{~km}$, especially in areas with altitude higher than 4000 a.s.l. The geographical locations of sampling sites were determined by a Global Positioning Satellite device together with records of altitude, soil condition, grassland type, and total vegetation cover. At each site $(50 \times 50 \mathrm{~m})$, all plants in plots $(1 \times 1 \mathrm{~m})$ were harvested to ground level to measure above-ground biomass. Belowground biomass was sampled by taking 2-10 soil cores of $12 \mathrm{~cm}$ diameter within each quadrate at depths of $0-10$, 
10-20, 20-40, 40-60, 60-80, and 80-100 cm. Roots and other belowground plant biomass, e.g., rhizomes contained within the excavated soil were separated with water through a $0.3-\mathrm{mm}$-mesh sieve. Biomass samples were oven-dried at $65^{\circ} \mathrm{C}$ to constant mass. A correction factor of 0.45 was applied to convert biomass to carbon. In situ air (Temp-air) and soil (Temp-soil) temperature was measured by putting mercury thermometer either $1 \mathrm{~m}$ above the ground or $15 \mathrm{~cm}$ below the ground.

Soil samples at each quadrate were obtained at depths of $0-10 \mathrm{~cm}$ and then handpicked to remove plant detritus and rock. All soil samples were sieved through a $2 \mathrm{~mm}$ mesh and grounded with a ball mill for carbon and nutrient analysis. Soil organic carbon content was analysed using wet oxidation method. Carbon contents (\%) of soil samples were converted to soil organic carbon (SOC) content $\left(\mathrm{kg} \mathrm{Cm}^{-2}\right)$ for a single layer:

$$
\mathrm{SOC}=C \times h \times \rho \times \mathrm{A},
$$

where $C$ represents carbon contents of soil samples (\%); $h$ represents soil layer thickness $(\mathrm{m}) ; \rho$ is the mean bulk density $\left(\mathrm{g} \mathrm{cm}^{-3}\right)$; A is the top surface area of soil core (104 $\mathrm{cm}^{-2}$ is this case).

Soil moisture was measured gravimetrically after $24 \mathrm{~h}$ desiccation at $105^{\circ} \mathrm{C}$. Bulk density was calculated as the ratio of the oven-dry soil mass to the volume $\left(\mathrm{g} \mathrm{cm}^{-3}\right)$ of soil cylinder. Soil texture was determined by particle size analyzer (Mastersizer 2000, Malvern, UK) after removal of organic matter and calcium carbonates. Mean annual temperature (MAT), mean annual precipitation (MAP), and accumulated annual temperature (the sum of temperature higher than zero degree, AAT) used in our analysis were derived from the climate database of the Tibetan Plateau at $0.1 \times 0.1$ degree resolution during 2001-2009. Because there was a quadratic relation between soil organic matter and MAT, a squared MAT was used to improve the fitness of regression analysis. The climate database was generated from records of 77 total climatic stations across the plateau, 45 of which located above $3000 \mathrm{~m}$ in elevation.

\subsection{Data analysis and statistic}

All data were tested for normality and made log-transformations when necessary. Ordinary least squares (OLS) regression analyses were conducted to evaluate the relationships between carbon stocks and local (including in situ measured air and soil temperature, soil moisture, soil bulk density and texture) and regional environmental variables including MAT, MAP, AAT, latitude, longitude, altitude. A stepwise regression was used to assess the impact of the "pure" local and regional factors and the interaction of them on carbon stocks. All analyses were performed using SAS 9.3 and figures were generated by using Sigmaplot 10.00 for Windows (SYSTAT Inc. Chicago, Illinois, USA).
Table 1. Plant and soil carbon contents of alpine steppe and alpine meadow grasslands in Tibetan Plateau

\begin{tabular}{lccc}
\hline \multicolumn{1}{c}{ Variables } & $\begin{array}{c}\text { Alpine } \\
\text { Steppe }\end{array}$ & $\begin{array}{c}\text { Alpine } \\
\text { Meadow }\end{array}$ & Mean \\
\hline $\begin{array}{l}\text { Above-ground } \\
\text { carbon content } \\
\left(\mathrm{kg} \mathrm{m}^{-2}\right)\end{array}$ & $0.029 \pm 0.024$ & $0.050 \pm 0.045$ & $0.039 \pm 0.036$ \\
$\begin{array}{l}\text { Belowground } \\
\text { carbon content } \\
\left(\mathrm{kg} \mathrm{m}^{-2}\right)\end{array}$ & $0.101 \pm 0.096$ & $0.335 \pm 0.296$ & $0.207 \pm 0.241$ \\
$\begin{array}{l}\text { Plant carbon } \\
\text { content }\left(\mathrm{kg} \mathrm{m}^{-2}\right)\end{array}$ & $0.129 \pm 0.103$ & $0.387 \pm 0.335$ & $0.249 \pm 0.244$ \\
$\begin{array}{l}\text { Soil carbon } \\
\text { content }\left(\mathrm{kg} \mathrm{m}^{-2}\right)\end{array}$ & $2.1 \pm 1.9$ & $4.2 \pm 4.1$ & $3.1 \pm 3.0$ \\
$\begin{array}{l}\text { Total carbon } \\
\text { content }\left(\mathrm{kg} \mathrm{m}^{-2}\right)\end{array}$ & $2.3 \pm 2.0$ & $4.3 \pm 4.1$ & $3.2 \pm 3.0$ \\
\hline
\end{tabular}

Note: soil carbon content is sampled to depth of $10 \mathrm{~cm}$. The same as below.

\section{Results}

\subsection{Spatial distributions of grassland carbon stocks}

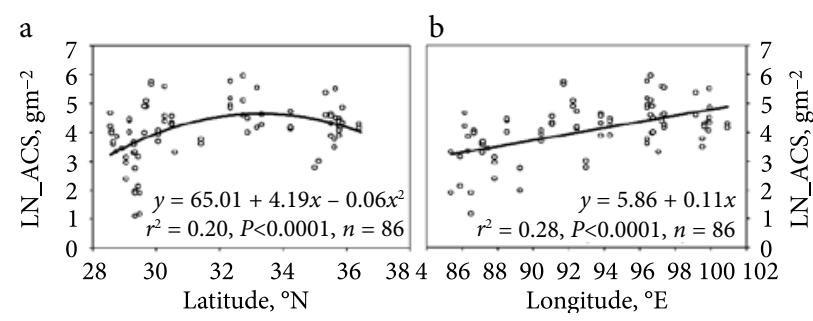

\section{政}

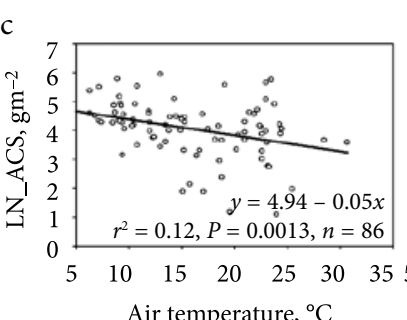

Fig. 1. Relationships between log-transformed above-ground carbon stock (ACS) and environmental variables: (a) latitude; (b) longitude; (c) air temperature; (d) soil moisture

\subsection{Environmental drivers of above-ground carbon (AGC) stocks}

Above-ground carbon content was mainly influenced by regional factors (Table 2$)$. AGC had significant $(P<0.001)$ unimodal and linear relationship, respectively, with latitude and longitude (Figs 1a, 2b). Although both air temperature and soil moisture had significantly $(P<0.01)$ correlated with AGC, they could only explain about $10 \%$ of the variation (Figs 1c, 2d). Step-wise regression results indicated that regional variables (latitude, longitude and mean annual temperature) explained $49.8 \%$ of the variation of AGC, while local factors (i.e. air temperature, soil 
water content, and sand content) explained less than one third of the variation (Table 3). Of the variables examined by regional factors, longitude explained the largest proportion $(88.4 \%)$ of the variation, followed by latitude (68.5\%) and annual accumulated temperature (51.4\%). At local scale, the AGC was mainly influenced by air temperature $(44.3 \%)$ and then followed by soil water content $(31.9 \%)$ and sand content $(27.9 \%)$. We then applied

Table 2. Summary of the results obtained from multiple linear regressions, showing the effects of regional and local factors on three carbon pools in alpine grassland of Tibetan Plateau

\begin{tabular}{|c|c|c|c|c|c|c|}
\hline & & & $\mathrm{CO}$ & SE & SC & $P$ value \\
\hline \multirow{6}{*}{$\begin{array}{l}\text { Above- } \\
\text { ground } \\
\text { carbon } \\
\text { content } \\
\left(\mathrm{g} \mathrm{m}^{-2}\right)\end{array}$} & \multirow{3}{*}{$\begin{array}{l}\text { Regio- } \\
\text { nal }\end{array}$} & Lat & -0.305 & 0.057 & -0.685 & $<0.0001$ \\
\hline & & Lon & 0.237 & 0.034 & 0.884 & $<0.0001$ \\
\hline & & AAT & -0.001 & 0.000 & -0.514 & $<0.0001$ \\
\hline & \multirow{3}{*}{ Local } & $\begin{array}{l}\text { Tem- } \\
\text { air }\end{array}$ & -0.091 & 0.021 & -0.443 & $<0.0001$ \\
\hline & & Sand & 0.02 & 0.008 & 0.279 & 0.012 \\
\hline & & & 0.359 & 0.121 & 0.319 & 0.004 \\
\hline \multirow{5}{*}{$\begin{array}{l}\text { Below- } \\
\text { ground } \\
\text { carbon } \\
\text { content } \\
\left(\mathrm{g} \mathrm{m}^{-2}\right)\end{array}$} & \multirow{2}{*}{$\begin{array}{l}\text { Regio- } \\
\text { nal }\end{array}$} & Lat & 0.085 & 0.039 & 0.21 & 0.032 \\
\hline & & MAT & -0.057 & 0.013 & -0.441 & $<0.0001$ \\
\hline & \multirow{3}{*}{ Local } & Clay & -0.645 & 0.315 & -0.164 & 0.044 \\
\hline & & $\mathrm{BD}$ & -0.783 & 0.411 & -0.261 & 0.060 \\
\hline & & SWC & 0.468 & 0.143 & 0.451 & 0.001 \\
\hline \multirow{3}{*}{$\begin{array}{l}\text { Soil } \\
\text { carbon } \\
\text { content } \\
\left(\mathrm{Kg} \mathrm{m}^{-2}\right)\end{array}$} & \multirow{2}{*}{$\begin{array}{l}\text { Regio- } \\
\text { nal }\end{array}$} & Lon & 0.091 & 0.016 & 0.5 & $<0.0001$ \\
\hline & & MAT & -0.023 & 0.008 & -0.25 & 0.005 \\
\hline & Local & SWC & 0.497 & 0.066 & 0.629 & $<0.0001$ \\
\hline
\end{tabular}

Abbreviations: ${ }^{+} \mathrm{CO}$ is coefficient; SE is standard error; SC is standardized coefficient; Lat is latitude; Lon is longitude; AAT is annual accumulated temperature; Tem-air is air temperature; Sand is soil sand content; SWC is soil moisture content; Clay is soil clay content; $\mathrm{BD}$ is soil bulk density; $\mathrm{MAT}^{2}$ is the square of mean annual temperature.

Table 3. Summary of the ANOVA results, shows the different influence of regional and local factors on three carbon pools in alpine grassland of Tibetan Plateau

\begin{tabular}{|c|c|c|c|c|c|c|}
\hline & & $\mathrm{SS}^{+}$ & MS & $R$ square & $F$ ratio & $P$ value \\
\hline \multirow{2}{*}{$\begin{array}{l}\text { Above- } \\
\text { ground } \\
\text { carbon } \\
\text { content } \\
\left(\mathrm{g} \mathrm{m}^{-2}\right)\end{array}$} & $\begin{array}{l}\text { Regio- } \\
\text { nal }\end{array}$ & 70.943 & 23.652 & 0.498 & 28.124 & $<0.0001$ \\
\hline & Local & 41.239 & 13.746 & 0.296 & 11.762 & $<0.0001$ \\
\hline \multirow{2}{*}{$\begin{array}{l}\text { Below- } \\
\text { ground } \\
\text { carbon } \\
\text { content } \\
\left(\mathrm{g} \mathrm{m}^{-2}\right)\end{array}$} & $\begin{array}{l}\text { Regio- } \\
\text { nal }\end{array}$ & 24.294 & 12.147 & 0.204 & 11.403 & $<0.0001$ \\
\hline & Local & 55.972 & 18.641 & 0.482 & 26.392 & $<0.0001$ \\
\hline \multirow{2}{*}{$\begin{array}{l}\text { Soil } \\
\text { carbon } \\
\text { content } \\
\left(\mathrm{Kg} \mathrm{m}^{-2}\right)\end{array}$} & $\begin{array}{l}\text { Regio- } \\
\text { nal }\end{array}$ & 21.657 & 10.892 & 0.331 & 21.731 & $<0.0001$ \\
\hline & Local & 26.398 & 13.199 & 0.407 & 29.112 & $<0.0001$ \\
\hline
\end{tabular}

variance partitioning method to estimate the contribution of local and regional factors to AGC, and found that only $3.1 \%$ of the variation of AGC was attributed to "pure" local factors, while $23.3 \%$ of the variation can be explained by "pure" regional factors (Fig. 2a). Overall results implied that the spatial distribution of AGC is mainly limited by regional factors, especially temperature.

\subsection{Environmental drivers of belowground carbon (BGC) stocks}

Unlike AGC, BGC was weakly related to regional factors (Table 2). Rather, significant relationships $(P<0.0001)$ were observed between BGC and soil water content $\left(r^{2}=\right.$ $42 \%)$, and between BGC and soil bulk density $\left(r^{2}=46 \%\right)$, though the overall trends were opposite (Fig. 3a, b). Notable, BGC showed a moderately significant negative relationship with mean annual temperature $\left(r^{2}=0.07, P=\right.$ 0.011) (Fig. 3c). Compared with regional factors, BGC was affected more strongly by local (20.4\% vs. $48.2 \%)$ factors (Table 3). The result of variance partitioning showed that only $9.0 \%$ of the BGC variation was attributed to "pure" regional factors, while $36.8 \%$ was explained by "pure" local factors (Fig. 2b). Of the variables examined by local factors, BGC was mainly controlled by soil water content $(45.1 \%)$, followed by bulk density $(26.1 \%)$, and clay content (16.4\%) (Table 2). In general, BGC is highly controlled by local factors, in particular soil moisture.

\subsection{Environmental drivers of soil organic carbon (SOC) stocks}

Both regional and local factors had relatively similar yet significant influence on SOC (Table 2). SOC had significant linear relationships with soil water content and longitude (Fig. 3d, e), but had a unimodal relationship with mean annual temperature (Fig. 3f). At regional scale, SOC was mainly constrained by longitude $(50.0 \%)$ and the square of mean annual precipitation (25.0\%), while limited by soil water content $(62.9 \%)$ at local scale. Stepwise regression suggested that the effects of regional and

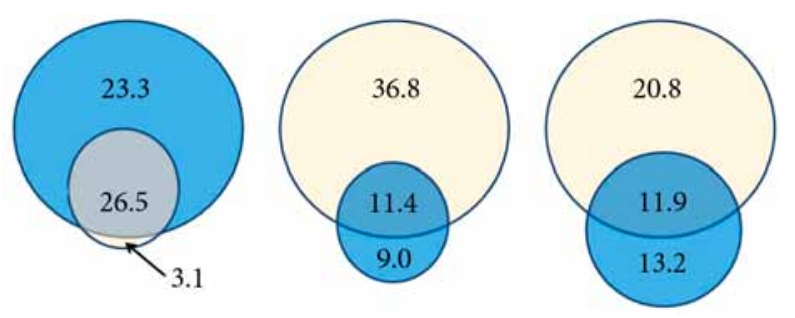

Fig. 2. Partitioning of the variances in carbon stock into percentages explained by regional properties (blue cycle), local factors (orange cycle), and their covariance (intersection). Numbers in the respective circles outside the intersection represent the variance explained by pure regional properties and pure local factors 
a

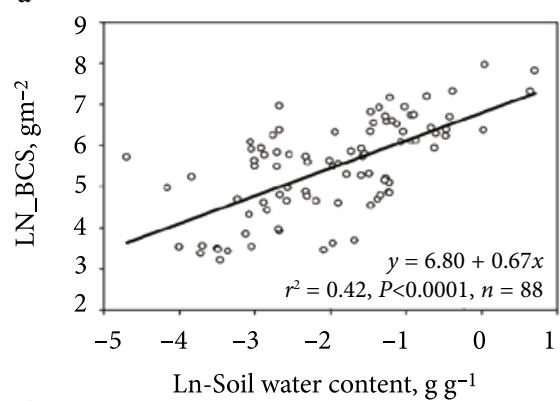

d

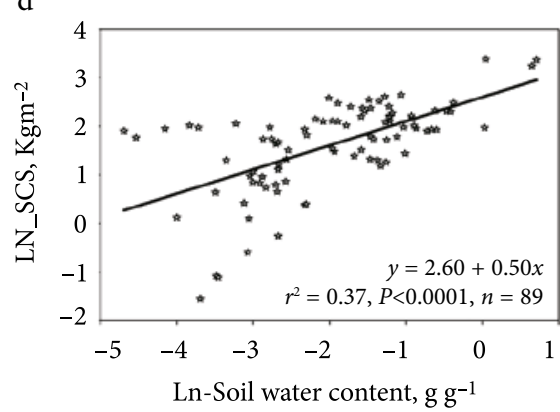

b

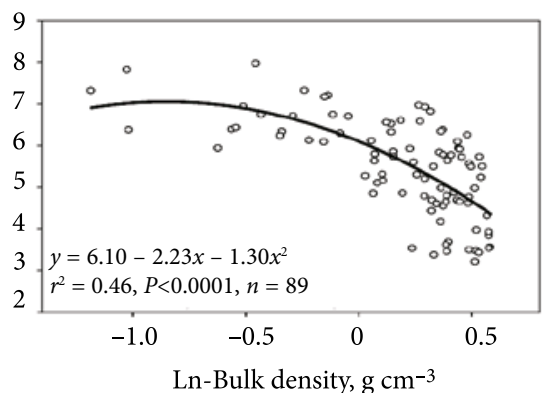$$
\text { e }
$$

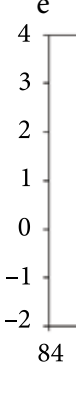

C

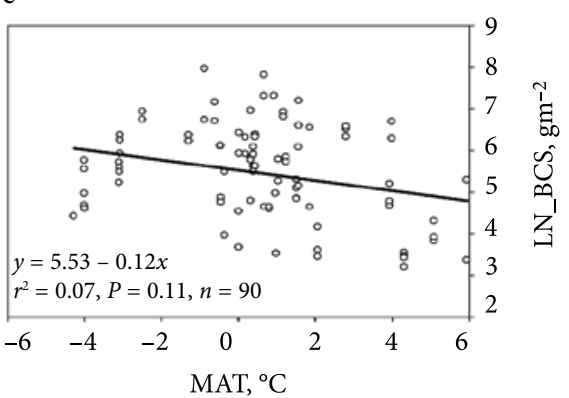

$\mathrm{f}$

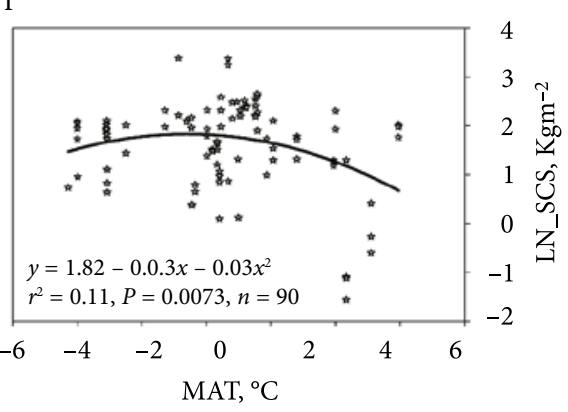

Fig. 3. Relationships of log-transformed belowground and soil carbon stock to environmental variables: (a) soil moisture; (b) soil bulk density; (c) mean annual temperature; (d) soil moisture; (e) longitude; (f) mean annual temperature. BCS is belowground carbon stock; SCS is soil carbon stock; MAT is mean annual temperature

local factors on soil organic carbon stock are relatively similar, with explaining 33.1 and $40.7 \%$ of the variation, respectively. Variance partitioning showed similar result, i.e. "pure" regional and "pure" local factors were compatible (13.2\% vs $20.8 \%)$ in explaining the variation of SOC.

\section{Discussion}

\subsection{Scale-specific responses of grassland carbon stocks to environmental drivers}

Carbon dynamics in Tibetan high-altitude grasslands are of special interest because of its high belowground carbon proportion and fragile feedbacks to climate change (Mack et al. 2004; Zimov et al. 2006; Davidson, Janssens 2006; Freschet et al. 2015). Responses of carbon dynamics to environmental factors remain uncertain in Tibetan plateau, mainly due to paucity of field belowground carbon data and high spatial heterogeneity (Jobbagy, Jackson 2000; Sun et al. 2013). Field belowground carbon survey and scaling-up approaches were thus combined to estimate ecosystem carbon content of grassland in those remote and high-altitude areas. There is an explicit fundamental assumption associated with scaling-up and/or scalingdown approach: the site-scale models should be applied to scale up to regional scales, i.e., the relationships between independent environmental predictors and carbon stocks dependent variables are applicable across various scales. Our study showed that the driving forces of aboveground carbon (AGC), belowground carbon (BGC), and SOC in the Tibetan Plateau were not constant, but strongly scale dependent (Table 2 and 3). The results of variance partitioning showed that the variation of AGC explained by "pure" regional factors was $7.8(23.3 \%$ vs $3.1 \%)$ times higher than "pure" local factors, while the variation of BGC was explained 4.1 (36.8\% vs $9.0 \%)$ times more by "pure" local factors than by "pure" regional factors. Compared with the significant but opposite patterns of regional and local factors on AGC and BGC, both local and regional factors had relatively similar (20.8\% vs. $13.2 \%)$ influence on SOC. Overall, temperature at large scales play an important role in AGC, whereas soil moisture availability constrains BGC, both of them determining SOC.

Such climatic variables controlling AGC at great geological scale and edaphic factors limiting BGC and SOC at fine-scale is caused by a couple of reasons. The first reason is sampling efforts. Ecosystem carbon stocks have been approximated by mean annual temperature and precipitation at large geological scale (Amundson 2001; Gibbon et al. 2010; Jiang et al. 2015). At small local scale, however, ecosystem carbon content vary with respect to simple, easily quantified soil variables such as soil nutrient availability, texture, and moisture (Wynn et al. 2006; Miao, Li 2007; Miao et al. 2011; Qin et al. 2015). Leith and Whittaker (1975) pointed out that these conflicting results regarding dissimilar driving factors of ecosystem processes at different spatial scales may be related to sampling efforts. They thought that climatic factors generally limit grassland production at a continental scale, but typically too broad to account for the observed variations in productivity at smaller geographic scales. The scale-dependent limiting 
factors of carbon stocks have important implications for continental to global scale carbon modeling efforts: the interpolating and/or extrapolating between small and large scales seem infeasible.

The second reason is the functional difference of plant organs. The functional difference between shoot and root, as well as the heterogeneous distribution of resources, such as solar radiation and moisture determine the response of AGC and BGC to environmental conditions, and hence SOC and the terrestrial ecosystem carbon cycling. Compared with edaphic variables such as soil moisture and nutrients, the distribution of solar energy and air temperature are highly homogeneous across the landscape. The main function of shoot is to absorb solar energy and transform it into bioavailable energy. Consequently, a positive relationship between AGC and temperature at large scales can be expected, since air temperature and solar irradiation are closely related (Piao et al. 2006; Sun et al. 2013). By contrast, root support life cycle of plants by providing water and nutrients, which are heterogeneously distributed either temperately or spatially. Keeping large root system will benefit to plants water budget by absorbing more water through increased absorption area. Tissues that are expensive to build because of a scarcity of mineral nutrients or slow acquisition of carbon should be long-lived because it will take longer for them to return the resources spent in constructing them to the plant. Consequently, plants growing on water limited sites often have long-lived leaves with low carbon-gaining capacities. Conversely, plants on water limited sites often have leaf tissues that require a shorter time period before the resources spent in building them are returned to the plant. Water addition in arid and semi-arid regions could stimulate root system growth by allocating more carbohydrate into root system (Chapin et al. 1986). As a result, the local factors play a determinative role in root growth, such as soil moisture and nutrient availability. The magnitude of SOC fundamentally depends on the rate of input (litter fall and find root) and output (decomposition and transport) (Amundson 2001). Despite this simplicity, measurement of SOC at regional scales is problematic, due to the heterogeneous distribution of SOC across the landscape and non-linear relationships between SOC, temperature and moisture (Davidson, Janssens 2006). Compared with the significant but opposite patterns of regional and local factors on the above- and below-ground carbon stock, both local and regional factors had relatively similar $(20.8 \%$ vs. $13.2 \%$ ) influence on SOC. It seems that the offsetting responses of AGC and BGC to air temperature and soil moisture seem to have negated any overwhelm influence of either resource on SOC. Our result generally in line with others that precipitation could stimulate plant production and thus contribute to the accumulation of soil organic matter in a water-limiting area (Jobbagy, Jackson
2000; Wynn et al. 2006; Miao et al. 2011). On the other hand, SOC tends to be high in cold and/or wet regions, owing to a combination of biological factors related to either high biomass productivity or slow decomposition, or both.

\subsection{Environmental drivers of Tibetan alpine carbon stocks}

As one of the largest alpine grasslands in the world, Tibetan Plateau is characterized by low temperature, long term snow coverage, and short growing season. It is generally assumed that projected global warming will benefit the Tibetan Plateau grassland carbon stock by prolonging growing season, promoting photosynthesis, and enhancing nutrient availability (Piao et al. 2006). However temperature showed linear and unimodal relationship, respectively, with plant and soil carbon stocks, implying complex impacts of global warming on the carbon stocks of Tibetan Plateau. The positive correlations between temperature and primary productivity are widely reported across various terrestrial ecosystems (Hui et al. 2005; Sun et al. 2013; Miao, Li 2010; Miao et al. 2011). The responses can also be related to the particular soil resource that is most limiting. For example increased temperature could also inhibit plant growth in arid regions due to worse soil moisture (Niu et al. 2008). In addition, increase in temperature could reduce nutrient supply as metabolic enhanced microbial will compete with plants for available resources (Rustad et al. 2001; King et al. 2008). In this study, the opposite trends of plant biomass and temperature indicated that AGC and BGC are not limited by temperature in Tibetan Plateau. By contrast, the overall unimodal relationships of SOC with MAT (mean annual temperature) revealed that SOC increased with MAT when MAT was lower than $-0.50{ }^{\circ} \mathrm{C}$, while SOC decreased with an increasing of temperatures when temperature is above $-0.50^{\circ} \mathrm{C}$. The decrease of SOC under moderate temperature $\left(-0.50{ }^{\circ} \mathrm{C}\right.$ of MAT) is likely due to the decrease of soil moisture with an increase of temperature.

Alpine regions are believed to be exposed to a higher rate of warming compared to any other parts of the globe and are most sensitive and vulnerable to global change (King et al. 2008). The strong significant $\left(r^{2}=0.42\right.$, $P<0.0001)$ linear relationship between BGC and soil moisture, and between SOC and soil moisture $\left(r^{2}=0.37\right.$, $P<0.0001)$ indicated that BGC and SOC were mainly limited by soil moisture. The weak relationships between BGC and MAT $\left(r^{2}=0.07, P=0.01\right)$ and between SOC and MAT $\left(r^{2}=0.11, P=0.01\right)$ suggested that temperature played a minor role in determining BGC and SOC. Our results were consistent with many other reports (Kardol et al. 2010; Wu et al. 2011). The scale-specific responses of AGC, BGC and SOC to temperature and moisture were helpful to predict the responses of alpine grassland 
community to warming-induced decrease of soil moisture in alpine grassland community. Climatic warming increases soil temperature and hence accelerate soil water transpiration by stimulating evapotranspiration (Rustad et al. 2001; Fontaine et al. 2004; Niu et al. 2008). Soil moisture aggravation will significant negatively impact on the above- and below-ground properties related to climate change. As a result, soil moisture variation is an important possible consequence of global warming. Although soil moisture was measured only one time, the significant correlation $\left(r^{2}=0.86, P<0.0001\right)$ between soil moisture and soil texture suggested a general trend of soil moisture distribution in the Plateau. Understanding interannual variation in carbon sequestration and allocation will require more detailed analysis of the influences of soil resources on the components of ecosystem carbon stocks.

\section{Conclusions}

Overall results indicated that the responses of above- and below-ground carbon stocks to environmental drivers are different in Tibetan alpine Plateau at both regional and local scales.

1. Aboveground carbon storage was mainly constrained by regional factors, especially air temperature.

2. Belowground carbon stocks was limited by local factors, especially soil moisture, whereas both regional and local factors had similar influence on soil carbon.

3. Global warming would reduce carbon stocks and complicate alpine grassland carbons mosaics, mainly caused by increasing air temperature and decreasing soil moisture.

\section{Acknowledgements}

We thank Dr. Laura Gough and Dr. Majie Fan for their valuable suggestions and reviewing early version. The authors are also grateful to Mei Hang, Zhengjia Liu, Xiujing Yang, Lei Li for assistance in field data collection, and Guiduo Shang, Lei Li, and Zhaosheng Wang for laboratory assistance. This work was supported by the National Natural Science Foundation of China. This research has been financially supported by the National Sciences Foundation of China (No. 30500067, 31070393, and 40975845).

\section{References}

Amundson, R. 2001. The carbon budget in soils, Annual Review of Earth Planet Sciences 29: 535-562.

http://dx.doi.org/10.1146/annurev.earth.29.1.535

Avohou, H. T.; Sinsin, B. 2009. The effects of topographic factors on aboveground biomass production of grasslands in the Atacora Mountains in North-western Benin, Mountain Research and Development 29(3): 250-254.

http://dx.doi.org/10.1659/mrd.00028
Bai, Y. F.; Wu, J. G.; Xing, Q.; Pan, Q.; Huang, J.; Yang, D.; Han, X. 2008. Primary production and rain use efficiency across a precipitation gradient on the Mongolia plateau, Ecology 89(8): 2140-2153. http://dx.doi.org/10.1890/07-0992.1

Bai, Y. F.; Han, X.; Wu, J.; Chen, Z.; Li, L. 2004. Ecosystem stability and compensatory effects in the Inner Mongolia grassland, Nature 431(7005): 181-184. http://dx.doi.org/10.1038/nature02850

Chabot, B. F.; Hicks, D. J. 1982. The ecology of leaf life spans, Annual Review of Ecology, Evolution, and Systematics 13: 229259. http://dx.doi.org/10.1146/annurev.es.13.110182.001305

Chapin, F. S.; Schulze, E. D.; Mooney, H. A. 1990. The ecology and economics of storage in plants, Annual Review of Ecology, Evolution, and Systematics 21: 423-47. http://dx.doi.org/10.1146/annurev.es.21.110190.002231

Chapin, F. S. III; Vitousek, P. M.; Cleve, K. V. 1986. The nature of nutrient limitation in plant communities, The American Naturalist 127(1): 48-58. http://dx.doi.org/10.1086/284466

Chinese Academy of Sciences. 2001. Vegetation atlas of China. Beijing: Science Press.

Davidson, E. A.; Janssens, I. A. 2006. Temperature sensitivity of soil carbon decomposition and feedbacks to climate change, Nature 440: 165-173. http://dx.doi.org/10.1038/nature04514

De Deyn, G. B.; Quirk, H.; Yi, Z.; Oakley, S.; Ostle, N. J.; Bardgett, R. D. 2009. Vegetation composition promotes carbon and nitrogen storage in model grassland communities of contrasting fertility, Journal of Ecology 97: 864-875.

http://dx.doi.org/10.1111/j.1365-2745.2009.01536.x

Enquist, B. J.; Niklas, K. J. 2002. Global allocation rules for biomass partitioning in seed plants, Science 295: 1517-1520. http://dx.doi.org/10.1126/science.1066360

Freschet, G. T.; Kichenin, E.; Wardle, D. A. 2015. Explaining within-community variation in plant biomass allocation: a balance between organ biomass and morphology above vs below ground?, Journal of Vegetation Science 26(3): 431-440. http://dx.doi.org/10.1111/jvs.12259

Fontaine, S.; Bardoux, G.; Abbadie, L.; Mariotti, A. 2004. Carbon input to soil may decrease soil carbon content, Ecology Letter 7(4): 314-320.

Gibbon, A.; Silman, M.; Malhi, Y.; Fisher, J. B.; Meir, P.; Zimmermann, M.; Dargie, G. C.; Farfan, W. R.; Garcia, K. C. 2010. Ecosystem carbon storage across the grassland-forest transition in the high Andes of Manu National Park, Peru, Ecosystems 13: 1097-1111. http://dx.doi.org/10.1007/s10021-010-9376-8

Gong, X. Y.; Fanselow, N.; Dittert, K.; Taube, F.; Lin, S. 2015. Response of primary production and biomass allocation to nitrogen and water supplementation along a grazing intensity gradient in semiarid grassland, European Journal Agronomy 63: 27-35. http://dx.doi.org/10.1016/j.eja.2014.11.004

Hendricks, J. J.; Nadelhoffer, K. J.; Aber, J. D. 1993. Assessing the role of fine roots in carbon and nutrient cycling, Trends in Ecology \& Evolution 8(5): 174-178. http://dx.doi.org/10.1016/0169-5347(93)90143-D

Hui, D.; Jackson, R. B. 2005. Geographic and interannual variability in biomass partitioning in grassland ecosystems: a synthesis of field data, New Phytologist 169(1): 85-93. http://dx.doi.org/10.1111/j.1469-8137.2005.01569.X

Jiang, Y.; Tao, J.; Huang, Y.; Zhu, J.; Tian, L.; Zhang, Y. 2015. The spatial pattern of grassland aboveground biomass on Xizang 
Plateau and its climatic controls, Journal Plant Ecology 8(1): 30-40. http://dx.doi.org/10.1093/jpe/rtu002

Jobbagy, E. G.; Jackson, R. B. 2000. The vertical distribution of soil organic carbon and its relation to climate and vegetation, Ecological Application 10(2): 423-436. http://dx.doi. org/10.1890/1051-0761(2000)010[0423:TVDOSO]2.0.CO;2

Kardol, P.; Campany, C. E.; Souza, L.; Norby, R. J.; Weltzin, J. F.; Classen, A. T. 2010. Climate change effects on plant biomass alter dominance patterns and community evenness in an experimental old-field ecosystem, Global Change Biology 16(12): 2676-2687.

http://dx.doi.org/10.1111/j.1365-2486.2010.02162.x

King, A. J.; Meyer, A. F.; Schmidt, S. K. 2008. High levels of microbial biomass and activity in unvegetated tropical and temperate alpine soils, Soil Biology \& Biochemistry 40: 26052610. http://dx.doi.org/10.1016/j.soilbio.2008.06.026

Knapp, A. K.; Fay, P. A.; Blair, J. M.; Collins, S. L.; Smith, M. D.; Carlisle, J. D.; Harper, C. W.; Danner, B. T.; Lett, M. S.; McCarron, J. K. 2002. Rainfall variability, carbon cycling, and plant species diversity in a mosaic grassland, Science 298: 2202-2205. http://dx.doi.org/10.1126/science.1076347

Leith, H.; Whittaker, R. (Eds.). 1975. Primary productivity of the biosphere. Berlin, Heidelberg, New York: Springer. http://dx.doi.org/10.1007/978-3-642-80913-2

Mack, M. C.; Schuur, E. A. G.; Bret-Harte, M. S.; Shaver, G. R.; Chapin F. S. III. 2004. Ecosystem carbon storage in arctic tundra reduced by long-term nutrient fertilization, Nature 431: 440-443. http://dx.doi.org/10.1038/nature02887

McConnaughay, K. D. M.; Coleman, J. S. 1999. Biomass allocation in plants: ontogeny or optimality? A test along three resource gradients, Ecology 80(8): 2581-2593. http://dx.doi. org/10.1890/0012-9658(1999)080[2581:BAIPOO]2.0.CO;2

Medvigy, D.; Wofsy, S. C.; Munger, J. W; Moorcroft, P. 2010. Responses of terrestrial ecosystems and carbon budgets to current and future environmental variability, Proceedings of the National Academy of Sciences 107(18): 8275-8280. http://dx.doi.org/10.1073/pnas.0912032107

Miao, Z.; Lathrop, R. G.; La Puma, I. P.; Clark, K. L.; Hom, J.; Skowronski, N.; Van Tuyl, S. 2011. Simulation and sensitivity analysis of carbon storage and fluxes in the New Jersey Pinelands, Environmental Modelling and Software 26(9): 1112-1122. http://dx.doi.org/10.1016/j.envsoft.2011.03.004

Miao, Z.; Li, C. 2007. Biomass estimates for major boreal forest species in west-central Canada. Canadian Wood Fibre Centre, Canadian Forest Service, Information Report FI-X-002, $1-37$.

Miao, Z.; Li, C. 2010. Predicting tree growth dynamics of boreal forest in response to climate change, in C. Li, R. Lafortezza and J. Chen (Eds.). Landscape Ecology in Forest Management and Conservation. Springer-HEP Publisher, 176-205.

Niu, S. L.; Wu, M. Y.; Han, Y., Xia, J.; Li, L.; Wan, S. 2008. Watermediated responses of ecosystem carbon fluxes to climatic change in a temperate steppe, New Phytologist 177(1): 209-219.

Ostertag, R. 2001. Effects of nitrogen and phosphorus availability on fine-root dynamics in Hawaiian montane forests, Ecology 82: 485-499. http://dx.doi.org/10.1890/00129658(2001)082[0485:EONAPA]2.0.CO;2

Patton, B. D.; Dong, X.; Nyren, P. E.; Nyren, A. 2007. Effects of grazing intensity, precipitation, and temperature on forage production, Rangeland and Ecological Management 60: 656665. http://dx.doi.org/10.2111/07-008R2.1
Piao, S. L.; Mohammat, A.; Fang, J. Y.; Cai, Q.; Feng, J. 2006. NDVI based increase in growth of temperate grasslands and its responses to climate changes in China, Global Environmental Change 16(4): 340-348.

http://dx.doi.org/10.1016/j.gloenvcha.2006.02.002

Qin, Y.; Yi, S.; Chen, J.; Ren, S.; Ding, Y. 2015. Effects of gravel on soil and vegetation properties of alpine grassland on the Qinghai-Tibetan plateau, Ecological Engineering 74: 351-355. http://dx.doi.org/10.1016/j.ecoleng.2014.10.008

Reich, P. B.; Walters, M. B.; Ellsworth, D. S. 1992. Leaf life-span in relation to leaf, plant, and stand characteristics among diverse ecosystems, Ecological Monograph 62(3): 365-392. http://dx.doi.org/10.2307/2937116

Rustad, L. E.; Campbell, J. L.; Marion, G. M.; Norby, R. J.; Mitchell, M. J.; Hartley, A. E.; Cornelissen, J. H. C.; Gurevitch, J. 2001. A meta-analysis of the response of soil respiration, net nitrogen mineralization, and aboveground plant growth to experimental ecosystem warming, Oecologia 126(4): 543562. http://dx.doi.org/10.1007/s004420000544

Sala, O. E.; Parton, W. J.; Joyce, L. A.; Lauenroth, W. K. 1988. Primary production of the central grassland region of the United States, Ecology 69: 40-45. http://dx.doi.org/10.2307/1943158

Scurlock, J. M. O.; Johnson, K.; Olson, R. J. 2002. Estimating net primary productivity from grassland biomass dynamics measurements, Global Change Biology 8(8):736-753. http://dx.doi.org/10.1046/j.1365-2486.2002.00512.x

Sistla, S. A.; Moore, J. C.; Simpson, R. T.; Gough, L.; Shaver, G. R.; Schimel, J. P. 2013. Long-term warming restructures Arctic tundra without changing net soil carbon storage, $\mathrm{Na}$ ture 497: 615-618.

http://dx.doi.org/10.1038/nature12129

Sun, J.; Cheng, G. W.; Li, W. P. 2013. Meta-analysis of relationships between environmental factors and aboveground biomass in the alpine grassland on the Tibetan Plateau, Biogeosciences 10: 1707-1715.

http://dx.doi.org/10.5194/bg-10-1707-2013

Swemmer, A. M.; Knapp, A.; Snyman, H. A. 2007. Intra-seasonal precipitation patterns and aboveground productivity in three perennial grasslands, Journal of Ecology 95(4): 780-788. http://dx.doi.org/10.1111/j.1365-2745.2007.01237.x

Wu, G. L.; Zhao, L. P.; Shi, Z. H.; Shang, Z. P. 2011. Above- and below-ground response to soil moisture change on an alpine wetland ecosystem in the Qinghai-Tibetan Plateau China, Biogeosciences Discussion 8(4): 7141-7164. http://dx.doi.org/10.5194/bgd-8-7141-2011

Wu, H; Guo, Z; Peng, C. 2003. Distribution and storage of soil organic carbon in China, Global Biogeochemical Cycles 17(2): 1048. http://dx.doi.org/10.1029/2001GB001844

Wynn, J. G.; Bird, M. I.; Vallen, L.; Grand-Clement, E.; Carter, J.; Berry, S. L. 2006. Continental-scale measurement of the soil organic carbon pool with climatic, edaphic, and biotic controls, Global Biogeochemical Cycles 20(1): GB1007. http://dx.doi.org/10.1029/2005GB002576

Xu, M.; Peng, F.; You, Q.; Guo, J.; Tian, X.; Xue, X.; Liu, M. 2015. Year-round warming and autumnal clipping lead to downward transport of root biomass, carbon and total nitrogen in soil of an alpine meadow, Environmental and Experimental Botany 109: 54-62. http://dx.doi.org/10.1016/j.envexpbot.2014.07.012

Yang, Y. H.; Fang, J. Y.; Ma, W. H.; Wang, W. 2008. Relationship between variability in aboveground net primary production 
and precipitation in global grasslands, Geophysical Research Letters 35(23): L23710.

http://dx.doi.org/10.1029/2008GL035408
Zimov, S. A.; Schuur, E. A. G.; Chapin, F. S. III. 2006. Permafrost and the global carbon budget, Science 312: 1612-1613. http://dx.doi.org/10.1126/science.1128908

Hongsheng LIU, PhD, research assistant, Institute of Geography Sciences and Natural Resource Research, Chinese Academy of Sciences, and Department of Biology, University of Texas at Arlington, USA. He is an author of about 30 publications. The major research area is ecosystem ecology.

Zewei MIAO, PhD, Research scientist, Nicholas School of the Environment, Duke University, USA. He is an author of about 50 publications. His major research area is eco-environmental modelling and biomass feedstock mechanical preprocessing for bioenergy production. Currently, he is an agronomic data scientist of Monsanto Co. 